\title{
Assessment of Soil pH and Heavy Metal Concentrations in Agricultural Land Impacted with Medical Waste Incinerator (MWI) Flue Ash (FA) in Abia State, Nigeria
}

\author{
${ }^{1 *}$ UBUOH, EA; ${ }^{1}$ UMEZURUIKE, SO; ${ }^{2}$ NWORUH, BO; ${ }^{3}$ EMEKA, CC
}

\author{
${ }^{*}$ Department of Environmental Management and Toxicology, Michael Okpara University of Agriculture, Umudike, Abia State, Nigeria \\ ${ }^{2}$ Department of Public Health, Federal University of Technology, Owerri, Nigeria \\ ${ }^{3}$ Department of Agriculture and Bio-resources Engineering, Michael Okpara University of Agriculture, Umudike, Abia State, Nigeria \\ *Corresponding Author Email: ubuohemmanuel@yahoo.com; Tel: +2348037639777
}

\begin{abstract}
This study focused on the effect of heavy metals being introduced into soils through medical waste incinerator flue ash by collecting soil samples at different depths and distances to determine soil $\mathrm{pH}, \mathrm{Cu}, \mathrm{Zn}, \mathrm{Cr}, \mathrm{Cd}, \mathrm{Pb}$ and $\mathrm{Mn}$ contents using standard methods and multivariate tools for data summary. Mean soil pH values ranged: $5.2-6.2$ $>4.8$ of control due to flue ash as a liming agent and farming practices respectively, with low $\mathrm{pH}$ that encourages mobility and absorption of heavy metals in ecosystems. Heavy metals in incinerator site $\left(\mathrm{mgkg}^{-1}\right)$ ranged:2.00105 $\pm 0.00-2.09050$ $\pm 0.00 ; \quad 4.0011 \pm 0.00-12.3250 \pm 0.00 ; \quad 6.0405 \pm 0.01-8.0150 \pm 0.01 ; \quad 4.0150 \pm 0.00-7.0805 \pm 0.07 ; 0.2100 \pm 0.01-1.0950 \pm 0.01 ;$ $0.00 \pm 0.00-0.001100 \pm 0.00 ; 0.0305 \pm 0.01-0.1150 \pm 0.00$ for $\mathrm{Cu}, \mathrm{Zn}, \mathrm{Mn}, \mathrm{Cr}, \mathrm{Cd}$ and $\mathrm{Pb}$ respectively, with control $0.55 \pm$ $0.01-1.25 \pm 0.01 ; 1.25 \pm 0.01-1.45 \pm 0.01 ; 13.15 \pm 0.07-14.15 \pm 0.07 ; 0.02 \pm 0.01 ; 0.00 \pm 0.01-0.03 \pm 0.01 ; .54 \pm 0.01-.54$ \pm 0.01 for $\mathrm{Cu}, \mathrm{Zn}, \mathrm{Mn}, \mathrm{Cr}, \mathrm{Cd}$ and $\mathrm{Pb}$ respectively .Metals were in order of: $\mathrm{Cd} \leq \mathrm{Cu} \leq \mathrm{Pb} \leq \mathrm{Cr} \leq \mathrm{Mn} \leq \mathrm{Zn}$ (LSD0.05). Result revealed that $\mathrm{Cr}, \mathrm{Cd}$ and $\mathrm{Pb}$ were below the limits for agricultural soil by FAO, and were higher at $50-100 \mathrm{~m}$ and decrease farther from incinerator. Negative correlation exists between $\mathrm{Cr}$ and $\mathrm{Zn} ; \mathrm{Zn}$ and $\mathrm{Cu}$ due to farming practices, $\mathrm{Mn}, \mathrm{Cd}$ recorded positive correlation due to incinerator flue ash. Factor 1 loaded $\mathrm{Cu}$ positively, $\mathrm{Cr}, \mathrm{Pb}, \mathrm{Mn}$, and $\mathrm{Zn}$ negatively loaded. Factor 2, exception of $\mathrm{Cr}, \mathrm{Cd}, \mathrm{Pb}$, and $\mathrm{Mn}$ loaded negatively due to flue gas and lithogenic respectively, C/PI indicated soil being slightly, moderately to severely contaminated respectively. $\mathrm{I}_{\text {geo }}$ indicated uncontaminated to moderately contaminated, showing that heavy metal contaminations of soils is minor.
\end{abstract}

\section{DOI: https://dx.doi.org/10.4314/jasem.v23i2.12}

Copyright: Copyright $(9) 2019$ Ubuoh et al. This is an open access article distributed under the Creative Commons Attribution License (CCL), which permits unrestricted use, distribution, and reproduction in any medium, provided the original work is properly cited.

Dates: Received: 20 December 2018; Revised: 21 January 2019; Accepted 27 January 2019

Keywords: Element, Incineration, Flue Smoke, Soil Acidity, multivariate analysis

Incineration of waste remains a disputed waste management disposal option in many countries of the world (Damgaard et al., 2010).Although incineration is a largely diffuse and effective way of treating solid waste, health effects associated with stack emissions remain a major public concern (Sofia and Lopes, 2017), and some toxics present in waste or formed during the process, may escape pollution control devices and be released to the atmosphere. Ultimately, these chemical scan cross environmental boundaries reaching different media: soil, water, biota, and vegetation (Gidarakos et al., 2009). As a result of the trans-boundary, human health can be directly or indirectly affected through different pathways including soil (USEPA, 1998a). Accordingly, incineration of medical waste also converts the waste into essentially non-combustible solid residue or ash (Gidarakos et al., 2009), and other outputs such as flue gas and heat (Samwel et al, 2012). Thus, the flue gases must be cleaned of gaseous and particulate pollutants before they are dispersed into the atmosphere (Samwel et al., 2012).Health-care waste has more heavy metals than municipal solid waste (Zhao et al., 2010). When health-care wastes are incinerated mercury $(\mathrm{Hg})$ residue is left in the bottom ash while the rest is released as gaseous emission typically called fly ash (FA), which is the by-product produced due to the combustion process (Valentim et al., 2009). The component of fly ash varies significantly, which depends on the makeup of waste burned. But all the fly ash includes some amount of silicon dioxide $\left(\mathrm{SiO}_{2}\right)$ both amorphous and crystalline and calcium oxide $(\mathrm{CaO})$ (Santosh, 2009). Flueash which is entrained in the flue gas, also contains trace amount of toxic metals (U, Th, $\mathrm{Cr}, \mathrm{Pb}, \mathrm{Hg}, \mathrm{Cd}$ etc), which may have negative effect on human health and plants due to low soil $\mathrm{pH}$ (Dhadse et al., 2009), which influenced the mobility and absorption of heavy metals in the soil (Violate $e t$ al., 2008). Such metal in fly ash can move through the air and deposited as dust or by precipitation that fall to the soil as contaminant and can seriously affect soil's ability to perform some of its key functions in the ecosystem (Ubuoh et al., 2014). Authors like Adama et al. (2016), Josephat et al. (2016) only worked on the characterization of incinerator bottom ash without looking at the effects of incinerator flue gas on soil for 
agricultural purposes. Accordingly, strong accumulation of heavy metals in agricultural soils has been reported by Xia et al. (2014), but there has been little research on the heavy metal distribution due to incinerator flue ash on agricultural land. Public concern about environmental pollution has focused attention on the disposal of urban and industrial waste hence this study intends to investigate the soil $\mathrm{pH}$ and heavy metal concentrations in agricultural land impacted with medical waste incinerator flue ash in Abia State, in view of interpreting the suitability of its soil for crop production.

\section{MATERIALS AND METHODS}

Study Area: This study was carried out in Medical Centre (MC) in Abia State, Nigeria. The state is located on Latitude $5^{0} 25 \mathrm{~N}$ and Longitude $7^{0} 30 \mathrm{E}$. The state covers an area of about 5,243.7 sq. km with a population of 2,833,999 (NPC, 2006). It has an average annual rainfall that ranges between 1900 $2200 \mathrm{~mm}$, almost evenly distributed throughout the wet season while temperature ranges between $21-27^{\circ} \mathrm{C}$ (NRCRI, 2014).

Soil Sampling Technique: Soil was sampled at four different sampling points away from the incinerator. Three of the sampling points were within $200 \mathrm{~m}$ from the incinerator (interval between sampling points were $50 \mathrm{~m}$ apart) at the windward direction, whereas the fourth point was $1,000 \mathrm{~m}$ in the demonstration farm, Michael Okpara University, Umudike (MOUAU) as control. Soil samples were collected at the depths: 0$15 \mathrm{~cm}, 15-30 \mathrm{~cm}$ using a Dutch soil auger and a spatula. The soil samples were dried at $105^{\circ} \mathrm{C}$ for 24 hours and then ground to a particle diameter of $<0.25 \mathrm{~mm}$ in an agate mortar (Shams and purkayastha , 2011), and were stored in labeled polythene bags and were taken to the laboratory for analysis of soil $\mathrm{pH}$ and heavy metals respectively.

Determination of soil $\mathrm{pH}$ and Heavy metals: The $\mathrm{pH}$ of soil was measured with the help of $\mathrm{pH}$ meter after filtered solution was measured (Shamsand purkayastha; 2011). For heavy metal determination in soil sampled, 1 gram of each of the sieved soil samples was digested using the nitric/perchloric acid digestion procedure. Presence of important heavy metals including copper $(\mathrm{Cu})$, zinc $(\mathrm{Zn})$, chromium $(\mathrm{Cr})$, cadmium $(\mathrm{Cd})$, lead $(\mathrm{Pb})$ and manganese $(\mathrm{Mn})$ were determined using Atomic absorption Spectrophotometer (AAS) (UnicamSolaar32 model) following the standard procedures as given in APHA (1995). All analyses were done in duplicates.

Multivariate Analytical Techniques: Multivariate statistics were employed to elicit quantitative information about the origin and relationship of potentially toxic elements in soils sampled (Borùvka et al., 2005).

The index of geo accumulation (I-geo):The degree contamination of heavy metals in soils was assessed with the geo-accumulation index $\left(\mathrm{I}_{\text {-geo }}\right)$ introduced by Muller (1969), taking into account the upper limit of background concentration. The method was employed in pollution assessment of heavy metals in urban soils, urban road dust and agricultural soils from China (Wei and Yang 2010). The geo-accumulation index is computed using the equation:

$$
\mathrm{I}_{\text {geo }}=\log 2\left(C n / 1.5^{B}\right) 2
$$

Where $\mathrm{Cn}$ is the measured content of the element in soil, and $\mathrm{B}_{\mathrm{n}}$ is the background value in soil. According to Muller (1969), the $I_{\text {-geo }}$ for each metal is calculated and classified as: uncontaminated ( $\left.\mathrm{I}_{\text {-geo }} \leq 0\right)$; slightly contaminated $\left(0<\mathrm{I}_{\text {-geo }} \leq 1\right)$; moderately contaminated $\left(1<\mathrm{I}_{\text {-geo }} \leq 2\right)$; moderately to heavily contaminated (2 $\left.<\mathrm{I}_{\text {-geo }} \leq 3\right)$; heavily contaminated $\left(3<\mathrm{I}_{\text {-geo }} \leq 4\right)$; heavily to extremely contaminated $\left(4<\mathrm{I}_{\text {-geo }} \leq 5\right)$; extremely contaminated ( $\left.\mathrm{I}_{\text {-geo }}>5\right)$.

Contamination /Pollution Index (C/PI):The contamination/pollution index was derived by employing the contamination/pollution index as defined by Lacutusu (2000), and Department of Petroleum Resources of Nigeria (DPR, 2002) for maximum allowed concentrations of heavy metals in soil and was used as follows: $\mathrm{Cd} 0.8 \mathrm{mg} \mathrm{kg}^{-1}, \mathrm{Cr} 100$ $\mathrm{mg} \mathrm{kg}{ }^{-1}$, Cu $36 \mathrm{mg} \mathrm{kg}^{-1}, \mathrm{~Pb} 85 \mathrm{mg} \mathrm{kg}^{-1}$, Zn $140 \mathrm{mg}$ $\mathrm{kg}^{-1}$ and $\mathrm{Mn} 850 \%$ derived from crustal abundance expressed as:

$$
\frac{\mathrm{C}}{\mathrm{PI}}=\frac{\text { Concentration of metal in soil }}{\text { Target value from reference table }}
$$

Table 1: Showing the significance of intervals of

\begin{tabular}{ll}
\multicolumn{2}{c}{ Contamination/Pollution Index (C/PI) } \\
\hline C/PI & Significance \\
\hline$<0.1$ & Very slight contamination \\
$0.10-0.25$ & Slight contamination \\
$0.26-0.5$ & Moderate contamination \\
$0.51-0.75$ & Severe contamination \\
$0.76-1.00$ & Very severe contamination \\
$1.1-2.0$ & Slight pollution \\
$2.1-4.0$ & Moderate pollution \\
$4.1-8.0$ & Severe pollution \\
$8.1-16.0$ & Very severe pollution \\
$>16.0$ & Excessive pollution \\
\hline \multicolumn{2}{c}{ Adapted from Lacutusu (2000). }
\end{tabular}

PLI value close to one, indicates heavy metal loads near the background level, while values above one, indicate soil pollution ( Liu et al., 2005).Therefore, soils with PLI value of more than 1 are polluted, whereas values less than 1 indicate no pollution 
(Harikumar et al., 2009). The significance of C/PI is indicated in Table 1.

Statistical Analysis: Results obtained from all samples were subjected to descriptive (mean, standard deviation and ranges) and inferential (ANOVA) statistics and $\mathrm{P}<0.05$ was considered to indicate statistical significance. Mean values were separated using Duncan's Multiple Range Test. To help in the identification of different soil parameters, Principal
Component (PC) analysis was performed to establish possible factors that contribute towards the concentrations and source apportionment of soil characteristics. The number of significant principal components was selected on the basis of varimax orthogonal rotation with Kaiser Normalization at Eigen values greater than 1 (Anyadike, 2009). The statistical analysis was performed using SPSS version 20. Geographical Positioning System (GPS) was used for soil sampling accuracy (Table 2).

\begin{tabular}{clll} 
Table 2: & Soil Sampling Points in Incinerator Flue Gas Site soil at Graded Distances and coordinates \\
\hline S/N & Soil sample & Distances & Coordinator \\
\hline 1 & Soil samples (1) & $50-100$ meters & Lat 5031'0.354N, Long 7.29038.292E \\
2 & Soil samples (2) & $100-150$ meters & Lat 5030'59.484N, Long 7029'38.736E \\
3 & Soil samples (3) & $150-200$ meters & Lat.5030'58.542N, Long 7029'38.94E \\
4 & Soil samples (4) & Control & Lat.5030'52.278N, Longitude 7 $7^{0} 30^{0} 0.378 \mathrm{E}$ \\
\hline
\end{tabular}

\section{RESULTS AND DISCUSSION}

The results in Table3-4 showed the mean, maximum, minimum values, standard deviation and variance of the effect of the flue ash on soil $\mathrm{pH}$ and heavy metals at graded distance. Table 5 shows correlation analysis of heavy metals. Table 6-7 indicate Eigen vector values for PC and contamination/Pollution Index of heavy metals in soil sample at graded distances respectively, and Table 8 shows contamination/geoaccumulation index of heavy metals in the soil at various distances. From the result in Table 3, soil pH (in $\mathrm{H}_{2} \mathrm{O}$ ) ranged between $5.150 \pm 0.00-5.900 \pm 0.07$ indicating slightly acidic and control with $4.81 \pm$ 0.01 indicating highly acidic at the depth of $0-15 \mathrm{~cm}$ respectively. Soil $\mathrm{pH}$ at $15-30 \mathrm{~cm}$ ranged between $5.250 \pm 0.00-6.400 \pm 0.07$ less acidic than control site with $4.51 \pm 0.01$. The overall average soil $\mathrm{pH}$ based on distance was in acidic order of $4.8<5.2>5.7>6.2$ signifying $\left(\mathrm{D}_{5}, \mathrm{D}_{2}, \mathrm{D} 4, \mathrm{D}_{1}\right)$. The effect of depth and distance was highly significant $(\mathrm{p} \leq 0.01)$ on the $\mathrm{pH}$ levels of the sampled soil.

The variation in soil acidity in the study site is suspected to be due to flue ashes added to the soil as liming agent while the control recorded very low $\mathrm{pH}$ suspected to be caused by farming practice. From Table 4, mean level $\left(\mathrm{mg} / \mathrm{kg}^{-1}\right)$ of $\mathrm{Cu}$ in topsoil ranged between 2.00105 $\pm 0.00-2.09050 \pm 0.00$ higher than control with $0.55 \pm 0.01$ and in subsoil $\mathrm{Cu}$ $: 2.00305 \pm 0.00-2.09100 \pm 0.00$ higher than control with $1.25 \pm 0.01, \mathrm{Zn}$ in topsoil : 4.0011 \pm 0.00 $12.3250 \pm 0.00$ far greater than control with $1.25 \pm 0.01$ and subsoil : 6.0150 $\pm 0.00-8.0150 \pm 0.01$ higher than control with $1.45 \pm 0.01, \mathrm{Mn}$ in topsoil :4.4500 \pm 0.01 $7.0805 \pm 0.07$ quite less than the control with $14.15 \pm$ 0.07 in subsoil: $\mathrm{Mn}$ in subsoil:2.0605 \pm 0.07 $6.0705 \pm 0.011$ less than control with $13.15 \pm 0.07, \mathrm{Cr}$ in topsoil : $0.2100 \pm 0.01$ and $1.0950 \pm 0.01$ slightly higher than control $(0.02 \pm 0.01$, and subsoil: $0.6050 \pm 0.01-1.7150 \pm 0.01$ higher than control with $0.02 \pm 0.01, \mathrm{Cd}$ in the topsoil :0.000300 \pm 0.00 $0.000305 \pm 0.00$ higher than control $-0.00020 \pm 0.01$ and at topsoil :0.001050 $\pm 0.00-0.000505 \pm 0.00$ far higher than control with $0.00 \pm 0.01$ and $\mathrm{Pb}$ in topsoil $: 0.0805 \pm 0.00-0.1050 \pm 0.00$ less than $1.63 \pm 0.01$ obtained from control., and the subsoil : 0.0305 $\pm 0.01-$ $0.1150 \pm 0.00$ lower than control with $1.54 \pm 0.01$ respectively. The $\mathrm{LSD}_{0.05}$ inter of heavy metals in soil affected by incinerator flue gas were in order of: $0.0002(\mathrm{Cd})<0.0019(\mathrm{Cu})<0.0100(\mathrm{~Pb})<0.0212(\mathrm{Cr})<$ $0.07135(\mathrm{Mn})<5.0208(\mathrm{Zn})$

From the correlation analysis in Table 5, Cr and $\mathrm{Zn}$; $\mathrm{Zn}$ and $\mathrm{Cu}$, had high significant negative relationship suggesting these heavy metals as a result of farming practices such as irrigation with sewage water, excessive fertilization, application of animal manure, and pesticide application while $\mathrm{Mn}$ and $\mathrm{Cd}$ had a high significant positive correlation in soil sampled . Factor 1 was positively loaded with $\mathrm{Cu}$ suspected to come from flue gas while negatively loaded with $\mathrm{Cr}, \mathrm{Pb}, \mathrm{Mn}$, and $\mathrm{Zn}$ with percentage variation of 43.60 , which is suspected to be predominantly lithogenic. Factor 2 was negatively loaded with $\mathrm{Cd}, \mathrm{Pb}, \mathrm{Mn}$ and positively loaded with $\mathrm{Cr}$ with percentage variation of 38.24.

Table 3: Mean \pm SD of the Effect of Incinerator Flue Gas on Soil pH at Graded Distances in Medical Centre, Abia State

\begin{tabular}{llllllc}
\hline Parameter & Depth & $* \mathrm{D}_{1}$ & $* \mathrm{D}_{3}$ & $\mathrm{D}_{3}$ & LSD $_{0.05}$ inter. & Control $\left(\mathrm{D}_{4}\right)$ \\
\hline $\mathrm{pH}\left(\mathrm{H}_{2} \mathrm{O}\right)$ & $0-15 \mathrm{~cm}\left(\mathrm{R}_{1}\right)$ & $5.900 \pm 0.00$ & $5.150 \pm 0.00$ & $5.900 \pm 0.07$ & & $4.81 \pm 0.01$ \\
& $15-30 \mathrm{~cm}\left(\mathrm{R}_{2}\right)$ & $6.400 \pm 0.07$ & $5.250 \pm 0.00$ & $5.450 \pm 0.07$ & $0.1153 * * *$ & $4.51 \pm 0.01$ \\
Average $\mathrm{pH}$ & - & $6.15 \pm 0.035$ & $5.2 \pm 0.00$ & $5.7 \pm 0.07$ & & $4.81 \pm 0.01$ \\
\hline \multicolumn{5}{c}{$*=D_{1}: 50-100 m ; D_{2}: 100-150 m ; D_{3}: 150-200 m,\left(\mathrm{D}_{4}\right):$ Control-1000m }
\end{tabular}

UBUOH, EA; UMEZURUIKE, SO; NWORUH, BO; EMEKA, CC 
Table 4: Mean \pm SD of the effect of Incinerator Flue Gas on Heavy Metal concentrations in Soil at Graded Distances in Medical Centre,

\begin{tabular}{|c|c|c|c|c|c|c|}
\hline Metal & $\begin{array}{l}\text { Soil } \\
\text { Depth }\end{array}$ & $* \mathrm{D}_{1}$ & $* \mathrm{D}_{2}$ & $* \mathrm{D}_{3}$ & $\begin{array}{l}\mathrm{LSD}_{0.05} \\
\text { inter. }\end{array}$ & Control \\
\hline \multirow[t]{2}{*}{$\mathrm{Cu}$} & $\mathrm{R}_{1}$ & $2.00105 \pm 0.00$ & $2.09050 \pm 0.00$ & $2.02050 \pm 0.00$ & & $0.55 \pm 0.01$ \\
\hline & $\mathrm{R}_{2}$ & $2.00305 \pm 0.00$ & $2.09100 \pm 0.00$ & $2.08050 \pm 0.00$ & $0.0019 * * *$ & $1.25 \pm 0.01$ \\
\hline \multirow[t]{2}{*}{$\mathrm{Zn}$} & $\mathrm{R}_{1}$ & $8.0150 \pm 0.03$ & $4.0011 \pm 0.00$ & $12.3250 \pm 0.00$ & & $1.25 \pm 0.01$ \\
\hline & $\mathrm{R}_{2}$ & $8.0150 \pm 0.01$ & $6.0405 \pm 0.01$ & $6.0150 \pm 0.00$ & $5.0208 * * *$ & $1.45 \pm 0.01$ \\
\hline \multirow[t]{2}{*}{$\mathrm{Mn}$} & $\mathrm{R}_{1}$ & $5.0550 \pm 0.00$ & $4.4500 \pm 0.01$ & $7.0805 \pm 0.07$ & & $14.15 \pm 0.07$ \\
\hline & $\mathrm{R}_{2}$ & $4.0150 \pm 0.00$ & $6.0705 \pm 0.01$ & $2.0605 \pm 0.07$ & $0.07135^{* * * *}$ & $13.15 \pm 0.07$ \\
\hline \multirow[t]{2}{*}{$\mathrm{Cr}$} & $\mathrm{R}_{1}$ & $1.0950 \pm 0.01$ & $0.2100 \pm 0.01$ & $0.6050 \pm 0.01$ & & $0.02 \pm 0.01$ \\
\hline & $\mathrm{R}_{2}$ & $1.7150 \pm 0.01$ & $0.8050 \pm 0.01$ & $0.6050 \pm 0.01$ & $0.0212 * * *$ & $0.02 \pm 0.01$ \\
\hline \multirow[t]{2}{*}{$\mathrm{Cd}$} & $\mathrm{R}_{1}$ & $0.000305 \pm 0.0$ & $0.001100 \pm 0.00$ & $0.000300 \pm 0.0$ & & $0.03 \pm 0.01$ \\
\hline & $\mathrm{R}_{2}$ & $0.000505 \pm 0.0$ & $0.001050 \pm 0.00$ & $0.000000 \pm 0.0$ & $0.0002 * *$ & $0.00 \pm 0.01$ \\
\hline \multirow[t]{2}{*}{$\mathrm{Pb}$} & $\mathrm{R}_{1}$ & $0.0905 \pm 0.01$ & $0.0805 \pm 0.00$ & $0.1050 \pm 0.00$ & & $1.63 \pm 0.01$ \\
\hline & $\mathrm{R}_{2}$ & $0.0705 \pm 0.00$ & $0.1150 \pm 0.00$ & $0.0305 \pm 0.01$ & $0.0100^{* * *}$ & $1.54 \pm 0.01$ \\
\hline
\end{tabular}

Table 5: Correlation Analysis of Heavy Metals of Soil in the Medical Incinerator Flue Gas Site

\begin{tabular}{|c|c|c|c|c|c|c|}
\hline Variable & Copper & Zinc & Manganese & Chromium & Cadmium & Lead \\
\hline Copper & 1 & & & & & \\
\hline \multirow[t]{2}{*}{ Zinc } & $-0.703 *$ & 1 & & & & \\
\hline & 0.011 & & & & & \\
\hline \multirow[t]{2}{*}{ Manganese } & -0.232 & 0.573 & 1 & & & \\
\hline & 0.469 & 0.051 & & & & \\
\hline \multirow[t]{2}{*}{ Chromium } & $-0.709 * *$ & 0.279 & -0.075 & 1 & & \\
\hline & 0.01 & 0.38 & 0.817 & & & \\
\hline \multirow[t]{2}{*}{ Cadmium } & 0.483 & -0.505 & 0.35 & -0.24 & 1 & \\
\hline & 0.111 & 0.094 & 0.264 & 0.453 & & \\
\hline \multirow[t]{2}{*}{ Lead } & -0.125 & 0.335 & $0.945 * *$ & -0.017 & 0.552 & 1 \\
\hline & 0.7 & 0.288 & 0 & 0.958 & 0.063 & \\
\hline
\end{tabular}

Table6: Eigen Vector Values for Principle Component of the effect of Hospital Incinerator Flue Gas on Heavy Metal

\begin{tabular}{lll}
\multicolumn{3}{c}{ concentrations } \\
\hline Variable & Factor 1 & Factor 2 \\
\hline Cadmium $(\mathrm{Cd})$ & 0.17476 & $-0.54934^{*}$ \\
Chromium $(\mathrm{Cr})$ & $-0.32795^{*}$ & $0.30285^{*}$ \\
Copper $(\mathrm{Cu})$ & $0.52225^{*}$ & -0.27343 \\
Lead $(\mathrm{Pb})$ & $-0.3334^{*}$ & $-0.54331^{*}$ \\
Manganese $(\mathrm{Mn})$ & $-0.41327^{*}$ & $-0.48055^{*}$ \\
Zinc $(\mathrm{Zn})$ & $-0.55427^{*}$ & 0.07508 \\
Eigen values & 2.616 & 2.294 \\
Percentage variation & 43.60 & 38.24 \\
Cumulative & 43.60 & 81.84 \\
\hline \multicolumn{3}{c}{}
\end{tabular}

Contamination/Pollution Index(C/PI) : The pollution load values from incinerator flue gas within 50 $200 \mathrm{~cm}$ varied between mean of $\mathrm{Cu}(0.057-0.058)$ signifying severe contaminated , Zn (0.036-0.057) moderate to severe contaminated, $\mathrm{Mn}(0.006), \mathrm{Cr}$ (0.005-0.014), $\mathrm{Cd}(0.001)$ and $\mathrm{Pb}(0.001)$ which is slightly contaminated respectively, which may cause severe, moderate and slight contaminated to soil if incinerator flue gas continued respectively (Table 7).

Contamination/Geo-Accumulation (I-geo): The values of $\mathrm{I}_{\text {-geo }}$ are shown in Table 8. Using the geoaccumulation indices, our study of soils within 50$200 \mathrm{~m}$ from the incinerator where flue gas, mean $\mathrm{Cu}$ ranged between -4.6915 to $-9.4389, \mathrm{Zn}-4.7141$ to -
9.2228, Mn-4.8235 to $-8.3841, \mathrm{Cr}-6.7764$ to -7.9658 , $\mathrm{Cd}-10.2877$ to -11.7027 and $\mathrm{Pb}-10.4103$ to -11.2877 which were found in the class 0 uncontaminated remark indicating uncontaminated to moderately contaminated soil.

Table7: Contamination/Pollution Index of Heavy Metals in Soil sample at Graded Distances at Incinerator Flue Gas Site

\begin{tabular}{llllllll}
\hline Distant & Soil & Cv & Zn & Mn & Cr & Cd & Pb \\
\cline { 2 - 8 } $50-100 \mathrm{~m}$ & $0-15$ & 0.056 & 0.057 & 0.006 & 0.011 & 0.000 & 0.001 \\
& $15-30$ & 0.058 & 0.057 & 0.005 & 0.017 & 0.001 & 0.000 \\
& Mean & 0.057 & 0.057 & 0.006 & 0.014 & 0.001 & 0.001 \\
& & SC & SC & SLC & SLC & SLC & SLC \\
& $0-15$ & 0.058 & 0.029 & 0.005 & 0.002 & 0.001 & 0.001 \\
& $15-30$ & 0.058 & 0.043 & 0.007 & 0.008 & 0.001 & 0.001 \\
$100-150 \mathrm{~m}$ & Mean & 0.058 & 0.036 & 0.006 & 0.005 & 0.001 & 0.001 \\
& & SC & MC & SLC & SLC & SLC & SLC \\
$150-200 \mathrm{~m}$ & $0-15$ & 0.058 & 0.029 & 0.005 & 0.002 & 0.001 & 0.001 \\
& $15-30$ & 0.058 & 0.043 & 0.007 & 0.008 & 0.001 & 0.001 \\
& Mean & 0.058 & 0.036 & 0.006 & 0.005 & 0.001 & 0.001 \\
& & SC & MC & SLC & SLC & SLC & SLC \\
\hline
\end{tabular}

$S C=$ severely contaminated SLT = slightly contaminated $M C=$ moderately contaminated

Soil $\mathrm{pH}$ is an important index of ecological condition of terrestrial environment (Yaseen et al., 2015). It is also reported that the $\mathrm{pH}$ of soils increases the mobility of $\mathrm{Pb}, \mathrm{Cd}, \mathrm{Cr}, \mathrm{Cu}, \mathrm{Hg}, \mathrm{Ni}$, and $\mathrm{Zn}$ in case of acidity while in alkaline condition the reverse phenomenon takes place (Gunjan and Neupane, 2015). The result of 
the study reveals that soil $\mathrm{pH}$ in the study location was slightly acidic with control location being highly acidic (Fig.1). The reason remains that the falling ash is a soil liming agent leading soil being slightly acidic. The result is consistent with the findings of Santosh (2009); Jason et al. (2016) who observed that storage of fly ash along with lime made the soil within paper industry alkaline due to increased $\mathrm{pH}$ to neutralize soil acidity at the surface. The result against the finding of Yaseen et al. (2015) who observed that the $\mathrm{pH}$ of soil was acidic near the kiln and neutral farther away.

Table 8: Contamination/geo-accumulation Index of Heavy Metals in the soil at Graded Distances at Incinerator Flue Gas Site

\begin{tabular}{|c|c|c|c|c|c|c|c|c|c|}
\hline Distant & Depths & $\begin{array}{l}\mathrm{Cu} \\
(\mathrm{mg} / \mathrm{kg})\end{array}$ & $\begin{array}{l}\mathrm{Zn} \\
(\mathrm{mg} / \mathrm{kg})\end{array}$ & $\begin{array}{l}\mathrm{Mn} \\
(\mathrm{mg} / \mathrm{kg})\end{array}$ & $\begin{array}{l}\mathrm{Cr} \\
(\mathrm{mg} / \mathrm{kg})\end{array}$ & $\begin{array}{l}\mathrm{Cd} \\
(\mathrm{mg} / \mathrm{kg})\end{array}$ & $\begin{array}{l}\mathrm{Pb} \\
(\mathrm{mg} / \mathrm{kg})\end{array}$ & $\begin{array}{l}\text { Lgeo } \\
\text { Class }\end{array}$ & Remark \\
\hline \multirow[t]{2}{*}{$50-100 m$} & $0-15$ & -4.7408 & -4.0905 & -7.4804 & -7.9658 & -11.7027 & -10.2877 & 1 & $\mathrm{UC}$ to $\mathrm{MC}$ \\
\hline & $15-30$ & -4.6981 & -5.1278 & -9.2877 & -7.9658 & - & -12.2877 & 1 & $\mathrm{UC}$ to $\mathrm{MC}$ \\
\hline Mean & Mean & -9.4389 & -9.2228 & -8.3841 & -7.9658 & -11.7027 & -11.2877 & 1 & $\mathrm{UC}$ to $\mathrm{MC}$ \\
\hline \multirow[t]{2}{*}{$100-150 \mathrm{~m}$} & $0-15$ & -4.7524 & -4.7141 & -4.6584 & -7.0979 & -11.7027 & -10.4804 & 1 & $\mathrm{UC}$ to $\mathrm{MC}$ \\
\hline & $15-30$ & -4.7524 & -4.7141 & -4.9885 & -6.4548 & -11.2877 & -10.9658 & 1 & $\mathrm{UC}$ to $\mathrm{MC}$ \\
\hline \multirow[t]{2}{*}{ Mean } & Mean & -4.7524 & -4.7141 & -4.8235 & -6.7764 & -11.4952 & -10.7231 & 1 & $\mathrm{UC}$ to $\mathrm{MC}$ \\
\hline & & & & & & & & 1 & \\
\hline \multirow[t]{2}{*}{$150-200 \mathrm{~m}$} & $0-15$ & -4.6915 & -5.7103 & -8.1584 & -9.5873 & -10.2877 & -10.7027 & 1 & $\mathrm{UC}$ to $\mathrm{MC}$ \\
\hline & $15-30$ & -4.6915 & -5.1178 & -7.7027 & -7.5573 & 10.2877 & -10.1178 & 1 & $\mathrm{UC}$ to $\mathrm{MC}$ \\
\hline Mean & Mean & -4.6915 & -5.4141 & -7.9306 & -8.55723 & -10.2877 & -10.4103 & 1 & $\mathrm{UC}$ to $\mathrm{MC}$ \\
\hline
\end{tabular}

Lower $\mathrm{pH}$ favors availability, mobility and redistribution of the metals in the various fractions due to increased solubility of the ions in acidic environment (Gunjan and Neupane, 2015; Jason et al., 2016; Olayinka et al, 2017). The result further shows that the effect of soil depths and distances were highly significant $(\mathrm{p} \leq 0.01)$ on the level of soil $\mathrm{pH}$ in the sampled soil.The result of the effect of incinerator flue gas on heavy metals in soil varied between incinerator site and control at different distances. This was observed by Wenchao et al.; (2018) who explained that concentration of heavy metals in soil showed marginally significant differences in distances ( $>0.1$ ), and the maximum concentrations of these heavy metals were close to municipal solid waste incinerator (MSWI) within $500 \mathrm{~m}$ and $1000 \mathrm{~m}$ distances (Afzali et al., 2014). Gunjan and Neupane (2015) also reported that the average metal concentration showed a diverse variation with respect to direction and distance. The correlation result showed that $\mathrm{Cr}$ and $\mathrm{Zn} ; \mathrm{Zn}$ and $\mathrm{Cu}$ recorded negative relationship suspected to come from farming practices. Sailu (2014) observed that agricultural practices such as application of fertilizers and pesticides are known to increase the concentration of heavy metals in the soil while $\mathrm{Mn}$ and $\mathrm{Cd}$ recorded positive correlation suspected to come from incinerator flue gas. The strong correlations observed indicate that each of the paired elements in the soil has common contamination sources which in this case may be linked to incinerator flue smoke in the study. Olayinkaet al., (2017) observed that higher concentration of cadmium at incinerator flue gas may be due to the wastes that contained Poly vinyl chloride (PVC), nickel-cadmium batteries.

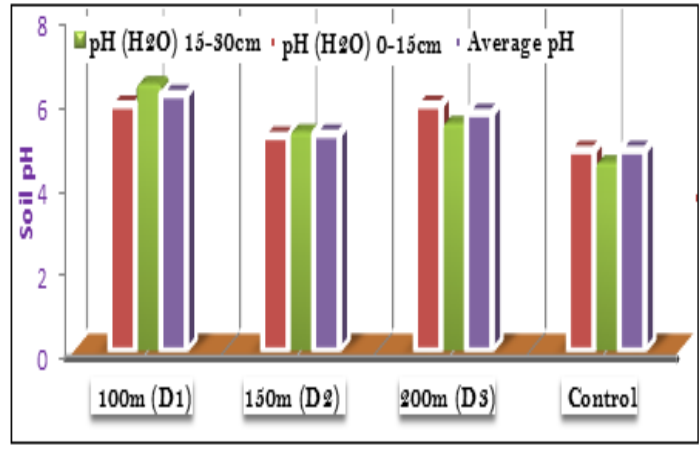

Fig 1: Variation of Soil pH in the Study and Control Locations in part of Abia State

The result of $\mathrm{Cr}$ obtained is lower than the critical permissible level which is $50 \mathrm{mg} / \mathrm{kg}^{1}$ for soil recommended for agriculture by MAFF (1992). Result of $\mathrm{Zn}$ correlation in soils obtained in the control is far below 548.56 - 642.94 obtained from hospital incinerator soil by Olayinka et al. (2017). These values are far lower than the natural limits of $0.01-3.0 \mathrm{mg} / \mathrm{kg}$ in soil as given by MAFF (1992), and lower than the tolerable soil contamination standard (SCS) and sediment quality guideline (SQG) levels of concentration (Xu-Chen et al., 2007).Positively loading in Factor 1 may be associated with flue gas while negatively loaded with $\mathrm{Cr}, \mathrm{Pb}, \mathrm{Mn}$, and $\mathrm{Zn}$ may be associated with lithogenic. The result is consistent with the finding of Mmolawa et al.,2011) who reported that $\mathrm{Mn}$ and $\mathrm{Zn}$ are lithogenic in Botswana soil whereas $\mathrm{Cu}$ originate from various anthropogenic sources and is commonly associated with atmospheric emission (Steinnes et al, 2000). This factor is inorganic with the Eigen value of 2.6616 and account for $43.60 \%$ of the total variance. Factor 2 was negatively loaded with $\mathrm{Cd}, \mathrm{Cu}, \mathrm{Pb}$ and $\mathrm{Mn}$ while $\mathrm{Cr}$ 
was positively loaded with the Eigen value of 2.94 accounting for $38.24 \%$ of the total variance. Result further indicated that $\mathrm{Cu}$ was positively loaded due flue gas while negatively loaded $\mathrm{Cr}, \mathrm{Pb}, \mathrm{Mn}$, and $\mathrm{Zn}$ were suspected to be due to the background values as lithogenic content, where environmental legislation has not yet established intervention limits for all environmental matrices (Albanese et al., 2007). The pollution load values from incinerator flue gas. $\mathrm{Cu}$ indicates severe contamination, $\mathrm{Zn}$ moderate to severe contamination, $\mathrm{Mn}, \mathrm{Cr}, \mathrm{Cd}$ and $\mathrm{Pb}$ slightly contamination respectively. This is in line with the findings of Chen et al. (1994) who observed the existence of slight contamination by heavy metals in Taiyuan topsoil. Using the geo-accumulation index, mean $\mathrm{Cu}, \mathrm{Zn}, \mathrm{Cr}, \mathrm{Cd}$, and $\mathrm{Pb}$ were found in the class 0 uncontaminated remarks indicating uncontaminated to moderately contaminated soil. This is at variance with the finding of Hosik (2009) who observed the values of geo-accumulated risk ( $\left.\mathrm{I}_{\text {-geo }}\right)$ to be moderately to strongly contaminated in soils.

Conclusion: The average metal concentrations showed a diverse variation with respect to soil depths and distances. The control site was highly acidic due to sharp farm practices while the study site was slightly acidic due to flue ash as liming agent that encouraged mobility and absorption of heavy metals in the soil. Heavy metals such as $\mathrm{Cr}, \mathrm{Cd}$ and $\mathrm{Pb}$ were below the limits for agricultural soil by FAO. Negative correlation exists between $\mathrm{Cr}$ and $\mathrm{Zn} ; \mathrm{Zn}$ and $\mathrm{Cu}$ due to farming practices, while $\mathrm{Mn}$ and $\mathrm{Cd}$ had positive correlation due to flue ash. C/PI shows slight, moderate and severe contaminations. $\mathrm{I}_{\text {-geo }}$ indicates uncontaminated to moderate contaminated due to medical waste incinerator flue gas.

Acknowledgment: The authors acknowledge Mr. Paul of Soil and Climate Change Laboratory, Federal Department Agricultural Land Resources and Climate Change Management, Abia State Unit for analysis of soil samples and his technical contribution during this study.

\section{REFERENCES}

Adama, MR; Esena, R; Fosu-Mensah, B; YirenyaTawiah, D (2016). Heavy Metal Contamination of Soils around a Hospital WasteIncinerator Bottom Ash Dumps Site. Hindawi Publishing Corporation. J. of Environ. Publ. Healt., Volume 2, p6.

Afzali, A; Rashid, M; Noorha, FK; Ammar, MR (2014). Evaluating human exposure to emission from incineration plant using AERMOD dispersion modeling. Iran. J. Public Health 433, $25-33$.

Albanese, SB; De-Vivo, AL; Cicchella, D (2007). Geochemical background and baseline values of toxic elements in stream sediments of Campania region (Italy). J. Geochem. Explo. 93: 21-34.

American Public Health Association (APHA) (1995).American Public Health Association. Standard Methods for the Examination of Water and Waste Water, 19thedn.APHA-AWWAWPCF, Washington, DC.pp. 525-987.

Anyadike, RNC (2009). Statistical Methods for the Social and Environmental Sciences. Spectrum Books, Ibadan.

Borùvka, LO; Vacek, BH; Jehlièka, J (2005). Principal Component Analysis as Tool to indicate the origin of potentially toxic elements in soils. Geoderma128: 289-300.

Chen, ZS; Lo, SL; Wu, HC (1994).Summary analysis and assessment of ruralsoils contaminated with $\mathrm{Cd}$ in Taoyuan.Project report of Scientific Technology Ad-visor Group (STAG), executive Yuan.Taipei, Taiwan. (In Chinese, with English abstract and Tables). (Unpub. mimeo-graph).

Damgaard, A; Riber, C; Fruergaard, T; Hulgaard, T; Christensen, TH (2010).Life-cycle-assessment of the historical development of air pollution control and energy recovery in waste incineration. Waste Manag. 30(7):1244-50.

Department of Petroleum Resources (DPR) (2002). Environmental guidelines and standards for the petroleum industry in Nigeria (revised edition).Department of Petroleum Resources, Ministry of Petroleum and Natural Resources, Abuja, Nigeria.

Dhadse, S; Pramila , K; Bhagia, LJ (2009). Fly ash characterization, Utilization and Government Initiatives in India .Review. J. of Sc. and Ind. Res., Vol 67, pp 11-18.

Gidarakos, EP; Anastasiadou, KM; Schramm, KWJ (2009). Characterization and hazard evaluation of bottom ash produced from incinerated hospital waste. J. of Hazardous Materials, 172, 935-942.

Gunjan, B; Neupane, S (2015): Impact of Brick Kilns' Emission on Soil Quality of Agriculture Fields in the Vicinity of Selected Bhaktapur Area of 
Nepal.Hindawi Publishing Corporation. Appl. and Environ. Soil Sci. Vol. 2015, Article ID 409401, 8 pages.

Harikumar, PS; Nasir, UP; Mujeebu, RM (2009). Distribution of heavy metals in the core sediments of a tropical wetland system; Int. J. of Environ. Sci. Techn. vol. 6, pp. 225-232.

Hosik, L; Md. Imran, K; Phil, SK; Jong, MK; Jong, GK; Seung, HH; Yeon, TR; Myoung, SB; Eul, RR; Myung, SJ (2009). Contamination assessment of abandoned mines by integrated pollution index in the Han River watershed. The Open Environ. Poll. \& Toxic. J., 1, pp. 27-33.

Jason, RB; David, MM; Kristofor, RB; Lisa, SW; ,Erik, DP (2016).Liming Characteristics of a High-Calcium Dry Flue Gas Desulfurization ByProductand a Class-C Fly Ash J. of Environ. Prot., , 7, 1592-1604.

Josephat, AM; Saria, P (2016). Health Risk Assessment Of Heavy Metals Via Consumption of Contaminated Vegetables Cultivated At Dar Es Salaam And Morogoro Regions In Tanzania. J. of Multi. Eng. Sci. Studies, Vol. 2(11), 1133- 1140.

Lacutusu, R (2000). Appraising level of soil contamination and pollution with heavy metals. In: Heinike HJ, Eckselman, W; Thomasson, AJ; Jones, RJA; Montanarella ; Buckleley, B. (eds). Land information systems for planning the sustainable use of land resources.European Soil Bureau Research Report.No. 4 office of official publication of the European Community's Luxembourg. Pp. 393-402.

Liu, X.; Gao -Yuntao, SK; Duan, G; Chen, A; Li , L; Zhao, L; Liu, Z; Wu, X (2005). Accumulation of $\mathrm{Pb}, \mathrm{Cu}$, and $\mathrm{Zn}$ in native plants growing on contaminated sites and their potential accumulation capacity in Heqing, Yunnan. $J$. of Environ. Sci., 20, 1469-1474.

Ministry of Agriculture, Fisheries and Food (MAFF) (1992). Code of Good Agriculture Practice for the Protection of Soil. Draft Consultation Document, MAFF, London.

Mmolawa 1, KB; Likuku, AS; Gaboutloeloe, GK (2011). Assessment of heavy metal pollution in soils along major roadside areas in Botswana. Afri. J. of Environ. Sci. and Techn. Vol. 5(3), pp. 186-196.
Müller, G (1969). "Index of geo accumulation in the sediments of the Rhine River," Geo Journal, 2(3): 108-118.

National Population Commission (NPC) (2006). National Population Commission Census Data, Abia State, Nigeria.

National Root Crop Research Institute, (NRCRI, 1995). Meteorological Data. Nigeria Tribune Newspaper, 18, 2010.pp.17-19.

Olayinka, O; Akande, OO; Bamgbose, K; Adetunji, MT (2017). Physicochemical Characteristics and Heavy Metal Levels in Soil Samples obtained from Selected Anthropogenic Sites in Abeokuta, Nigeria. J. Appl. Sci. Environ. Manage. Vol. 21 (5) $883-891$.

Sailus, MI (2014). Determination of the levels of selected heavymetals in soil and in khat(Catha edulis Forsk) Grown inKenya. A Thesis Submitted in Partial Fulfillment of the Requirements for the Award of the Degree of Master of Science (Analytical Chemistry) in the School of Pure and Applied Sciences of Kenyatta University.

Samwel, VM; Ignatio, SK (2012). Analysis of Medical Waste Incinerator Performance Based on Fuel Consumption and Cycle Times. Engineering, 4, 625-635.

Santosh, K. (2009). Leaching Behaviour of Elements from Sub-bituminous Coal Fly Ash. BSc. Project submitted to the Dept. of Mining Engineering National Institute of Technology Rourkela 769008, pp.1-33.

Shams, MT; Purkayastha, T (2011). Heavy metal assessment of incinerated medical waste, Bachelor of Science, Engineering thesis, Department of Civil and Environmental Engineering, Shahjalal University of Science \& Technology, Sylhet, Bangladesh

Singh, G; Kumari, V (1999). Environmental Assessment of Fly ash in its disposal Environment at FCI Itd, Sindri, Poll. Res. 18, 339-349.

Sofia, SA; Lpoes, M (2017). Environmental Aspects and Impacts of a waste incinerator plant. $4^{\text {th }}$ International Conference on Energy and Environmental Research, ICEER, 17-20, July, Porto, Portugal. 
Steinnes, EN; Lukina, V; Nikonov, D; Aalmlid, OR (2000). Gradient study of 34 elements in the vicinity of a copper-nickel smelter in the Kola Peninsula, Environ. Monit. Assess. Vol.60, 71-78.

Ubuoh, EA; Nwawuike, N; Obeta, MC (2014). Environmental Risk Assessment of Heavy Metal Concentrations in Road Runoff with Absorption Atomic Spectrophotometer, Imo State, Nigeria.J. Environ. Earth Sci. (USA) Vol. 4 No. 5. ISSN $2225-0948$.

United States Environmental Protection Agency (USEPA) (1998a). Methodology for Assessing Health Risks Associated with Multiple Pathways of Exposure to Combustor Emissions. EPA 600/R- 98-137, National Center for Environmental Assessment, Cincinnati, $\mathrm{OH}$.

Valentim, B; Guedes, AA; Flores, D; Ward, CR ; Hower, JC (2009).Variations in fly ash Compositions in the sampled locations: Case study from Portuguese power plant. Coal Combustion and Gasification Products, 1, 14-24.

Violate, A; Krisrinamuri, GSR; Pigna, M (2008). Mobility of trace element in soil environment. In: violante, A.; Huang, P.M. and Gadd, G.M., editior. Biophysico-chemical processes of metals and metal loids in soil environment, Hoboken: Wiley; p.169-213.
Wenchao, ML; Zhi; Lei, Z; ,Zhen, WK; Guanyi, C (2018). Contamination source apportionment and health risk assessment of heavy metals in soil around municipal solid waste incinerator: A case study in North China. Sci. of the total Environ. 631-632, 348-357.

Xia, XQ; Yang, ZF; Cui , YJ; Li , YS; Hou, QY; $\mathrm{Yu}, \mathrm{T}$ (2014). Soil heavy metal concentrations and their typical input and output fluxes on the southern Songnen Plain, Heilongjiang Province, China. J Geochem Explor. 139: 85-96.

Xu-Chen, W; Huan, F; Hai-Qing, M (2007). Assessment of metal contamination in surface sediments of Jiaozhou bay, Qingdao, China. Clean, 35 (1), pp. $62-70$.

Yaseen, S; Pal, A; Singh, S; Skinder, BM (2015). Soil quality of agricultural fields in the vicinity of selected mining areas of Raniganj Coalfield India, J. of Environ. \& Anal. Toxic. vol. 5, no. 3, article 269.

Zhao, L; Zhang; FS; Chen, M; Liu, Z; Wu, DB (2010). Typical pollutants in bottom ashes from a typical medical waste incinerator, J. of Haz. Mat., vol. 173, no. 1-3, pp. 181-185. 